\title{
CBD as the New Medicine in the Pain Provider's Armamentarium
}

Charlie Piermarini · Omar Viswanath

Received: February 26, 2019 / Published online: March 12, 2019

(C) The Author(s) 2019

Keywords: Cannabidiol; CBD; Chronic pain; Non-opioid; Opioids; Pain medicine

Following the recent publication "An Update of Current Cannabis-based Pharmaceuticals in Pain Medicine," [1] we felt compelled to highlight and expound upon an important point mentioned in the review. As providers who currently treat some chronic pain patients with CBD oil as part of a multimodal analgesic treatment regimen, we have found great benefit of this new weapon recently being utilized in our armamentarium. As mentioned in the article, the current political climate surrounding CBD is both vague and ever-changing, which

Enhanced digital features To view enhanced digital features for this article go to https://doi.org/10.6084/ m9.figshare.7777118.

C. Piermarini · O. Viswanath ( $\square)$

Valley Pain Consultants, Phoenix, AZ, USA

e-mail: viswanoy@gmail.com

C. Piermarini

Restorative Care Arizona, Phoenix, AZ, USA

O. Viswanath

Department of Anesthesiology, University of Arizona College of Medicine-Phoenix, Phoenix, AZ, USA

O. Viswanath

Department of Anesthesiology, Creighton

University School of Medicine, Omaha, NE, USA can and does impact treatment and subsequent patient outcomes as pain medicine providers.

We are at the forefront of change in the cannabis industry and with that comes uncertainty in not only treatment modalities but also safety and long-term side effects. The article mentions, "And while there are concerns over the relatively unknown long-term consequence of cannabis use, its use in medical management is surely to continue." Patient's use of CBD oil and other cannabis-related products continue to rise and with that comes the subsequent gold rush of people trying to make money of the naivety of patients looking for something to treat their conditions. This leads to many products being put on the market that are either mislabeled, contain no CBD, or even worse contain unintended dangerous hormones due to their production in China. This is well documented in the JAMA article in 2017 titled: "Labeling Accuracy of Cannabidiol Extracts Sold Online" [2].

This results in the patients shouldering the burden of sorting through the hundreds of companies to find a legitimate or trustworthy CBD oil. As referred to in the article, CBD can elevate liver enzymes and is metabolized through the similar liver pathways of many common prescription medications, which can cause unintended side effects of other medications they may be taking on a daily basis. Chronic pain patients should not be tasked with 
having to distinguish between legitimate and potentially harmful CBD products.

If we want to make cannabis and CBD into a legitimate medicinal treatment, there must be more regulations on CBD oil production and accurate labeling. Patients will continue to seek CBD oil as an additional option to treat their chronic pain as it gains popularity, so it is our duty as providers to protect them and ensure they have safe options of this new medication to choose from.

\section{ACKNOWLEDGEMENTS}

Funding. No funding or sponsorship was received for this study or publication of this article.

Authorship. All named authors meet the International Committee of Medical Journal Editors (ICMJE) criteria for authorship for this article, take responsibility for the integrity of the work as a whole, and have given their approval for this version to be published.

Disclosures. Charlie Piermarini is the Founder/CEO of Restorative Care Arizona. Omar Viswanath has nothing to disclose.

Compliance with Ethics Guidelines. This article is based on previously conducted studies and does not contain any studies with human participants or animals performed by any of the authors.

Peer Review. Please note, contrary to the journal's standard single-blind peer-review process, as a letter this article underwent review by a member of the journal's Editorial Board.

Open Access. This article is distributed under the terms of the Creative Commons Attribution-NonCommercial 4.0 International License (http://creativecommons.org/licenses/ by-nc/4.0/), which permits any noncommercial use, distribution, and reproduction in any medium, provided you give appropriate credit to the original author(s) and the source, provide a link to the Creative Commons license, and indicate if changes were made.

\section{REFERENCES}

1. Urits I, Borchart M, Hasegawa M, Kochanski J, Orhurhu V, Viswanath O. An update of current cannabis-based pharmaceuticals in pain medicine. Pain and Therapy. 2019. https://doi.org/10.1007/ s40122-019-0114-4.

2. Bonn-Miller MO, Loflin MJE, Thomas BF, Marcu JP, Hyke T, Vandrey R. Labeling accuracy of cannabidiol extracts sold online. JAMA. 2017;318(17):1708-9. 